\title{
Observations of the F-region ionospheric irregularities in the South American sector during the October 2003 "Halloween Storms"
}

\author{
Y. Sahai ${ }^{1}$, F. Becker-Guedes ${ }^{1,7}$, P. R. Fagundes ${ }^{1}$, A. J. de Abreu ${ }^{1}$, R. de Jesus ${ }^{1}$, V. G. Pillat ${ }^{1}$, J. R. Abalde ${ }^{1}$,

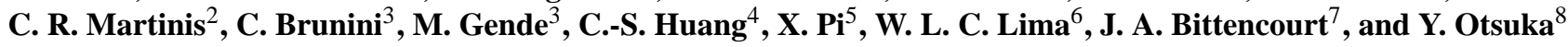 \\ ${ }^{1}$ Department of Physics and Astronomy, Universidade do Vale do Paraíba (UNIVAP), Sao Jose dos Campos, SP, Brazil \\ ${ }^{2}$ Center for Space Physics, Boston University, Boston, MA, 02215, USA \\ ${ }^{3}$ Facultad de Ciencias Astronómicas y Geofísicas, Universidad Nacional de La Plata, 1900, La Plata, Argentina \\ ${ }^{4}$ Institute for Scientific Research, Boston College, Chestnut Hill, MA 02467, USA \\ ${ }^{5}$ Jet Propulsion Laboratory, Pasadena, CA 91109, USA \\ ${ }^{6}$ Centro Univ. Luterano de Palmas (CEULP), Universidade Luterana do Brasil (ULBRA), Palmas, TO, Brazil \\ ${ }^{7}$ Instituto Nacional de Pesquisas Espaciais (INPE), Sao Jose dos Campos, SP, Brazil \\ ${ }^{8}$ Solar-Terrestrial Environment Laboratory Nagoya University, Nagoya, Aichi, 464-8601, Japan
}

Received: 10 September 2009 - Revised: 27 November 2009 - Accepted: 30 November 2009 - Published: 8 December 2009

\begin{abstract}
The response of the ionospheric F-region in the South American sector during the super geomagnetic storms on 29 and 30 October 2003 is studied in the present investigation.
\end{abstract}

In this paper, we present ionospheric sounding observations during the period 29-31 October 2003 obtained at Palmas (a near equatorial location) and Sao Jose dos Campos (a location under the southern crest of the equatorial ionospheric anomaly), Brazil, along with observations during the period 27-31 October 2003 from a chain of GPS stations covering the South American sector from Imperatriz, Brazil, to Rio Grande, Argentina. Also, complementary observations that include sequences of all-sky images of the OI 777.4 and $630.0 \mathrm{~nm}$ emissions observed at El Leoncito, Argentina, on the nights of 28-29 (geomagnetically quiet night) and 29-30 (geomagnetically disturbed night) October 2003, and ion densities observed in the South American sector by the DMSP F13, F14 and F15 satellites orbiting at about $800 \mathrm{~km}$ on 29 and 30 October 2003 are presented. In addition, global TEC maps derived from GPS observations collected from the global GPS network of International GPS Service (IGS) are presented, showing widespread and drastic TEC changes during the different phases of the geomagnetic disturbances. The observations indicate that the equatorial ionospheric irregularities or plasma bubbles extend to the Argentinean sta-

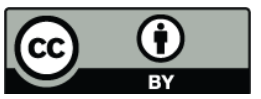

Correspondence to: Y. Sahai (sahai@univap.br) tion Rawson (geom. Lat. $33.1^{\circ} \mathrm{S}$ ) and map at the magnetic equator at an altitude of about $2500 \mathrm{~km}$.

Keywords. Ionosphere (Ionosphere-magnetosphere interactions; Ionospheric disturbances; Ionospheric irregularities)

\section{Introduction}

Interactions between the magnetosphere and the ionosphere during intense geomagnetic storms continue to be an important subject related to space weather studies. Ionospheric storms are closely associated with geomagnetic storms. Buonosanto (1999) has indicated that ionospheric storms represent an extreme form of space weather with important effects on ground and space-based technological systems. As described by Gopalswamy et al. (2005) the solar-terrestrial events of late October and early November 2003, popularly referred as the Halloween storms, represent the best observed cases of extreme space weather activity observed to date and have generated research covering multiple aspects of solar eruptions and their space weather effects. Tsurutani et al. (2005) and Sahai et al. (2005) have mentioned that on 28 and 29 October launch of fast coronal mass ejections (CMEs) were associated with the solar flares and their impacts on the Earth's magnetosphere resulted in major geomagnetic storms on 29 and 30 October (Halloween storms). The geomagnetic storms on the 29 and 30 October (and their interplanetary causes) were discussed in greater detail by $\mathrm{Wu}$ et al. (2005) and Mannucci et al. (2005). Several investigators

Published by Copernicus Publications on behalf of the European Geosciences Union. 


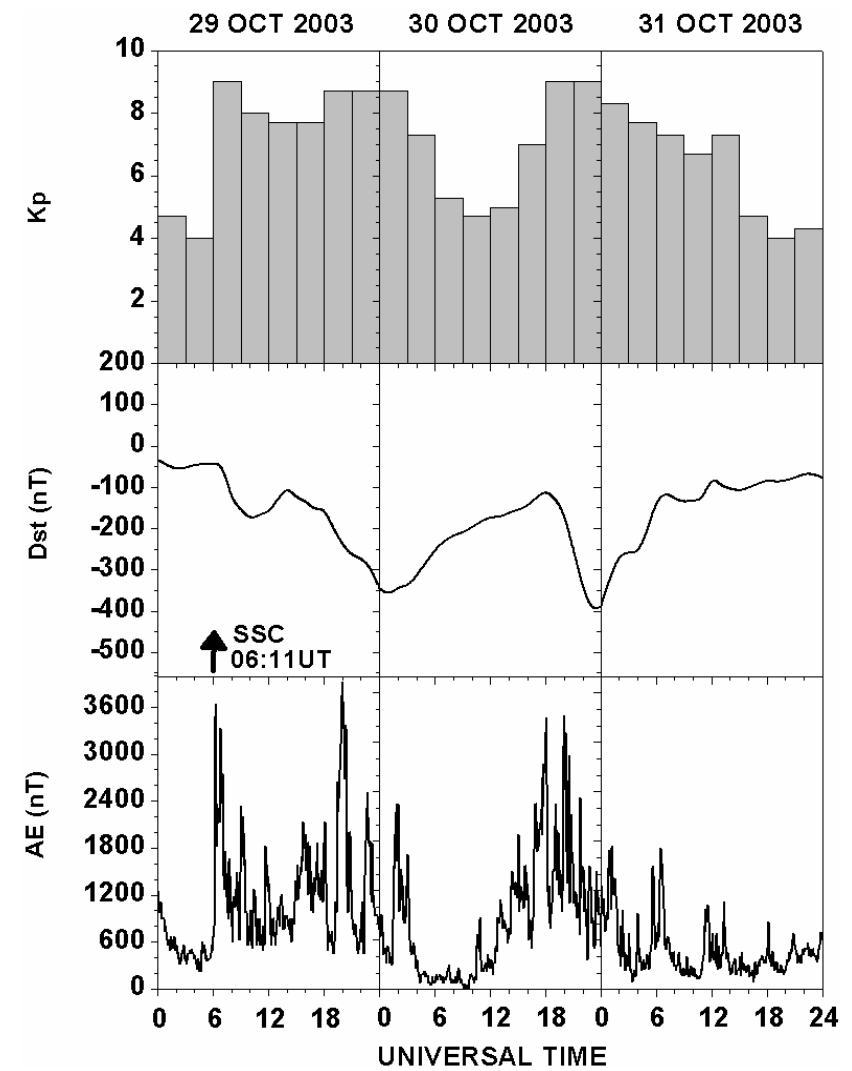

Fig. 1. Time variations of the $K_{p}, D_{s t}$ and AE geomagnetic indices for the period 29 to 31 October 2003.

have studied the response of the ionospheric F-region in the equatorial and mid-latitude regions during the October 2003 Halloween storms (e.g., Basu et al., 2005, 2007; Foster and Rideout, 2005; Lin et al., 2005; Zhao et al., 2005; Sahai et al., 2005; Yizengaw et al., 2005; Chi et al., 2005; Batista et al., 2006; Garner et al., 2006; Abdu et al., 2007, 2008; Huang et al., 2007; Mannucci et al., 2008; Perevalova et al., 2008; Tsurutani et al., 2008; Verkhoglyadova et al., 2008).

During the recent past several excellent reviews related to the effects of geomagnetic storms on the equatorial and mid-latitude ionospheric regions have been published (e.g., Schunk and Sojka, 1996; Abdu, 1997; Buonosanto, 1999; and Tsurutani et al., 2008). However, studies of magnetosphere-ionosphere interactions during intense geomagnetic storms at equatorial and mid-latitude regions continue to attract considerable attention of different investigating (both observational and modeling) groups. Case study for the ionospheric storm is still important to enrich our current understanding and to verify whether the observed storm effects can be explained by the established theories. The continued interest in these studies is related to the lack of understanding and our inability to predict well the space weather response of the thermospheric and ionospheric regions. It appears that there are several drivers of the

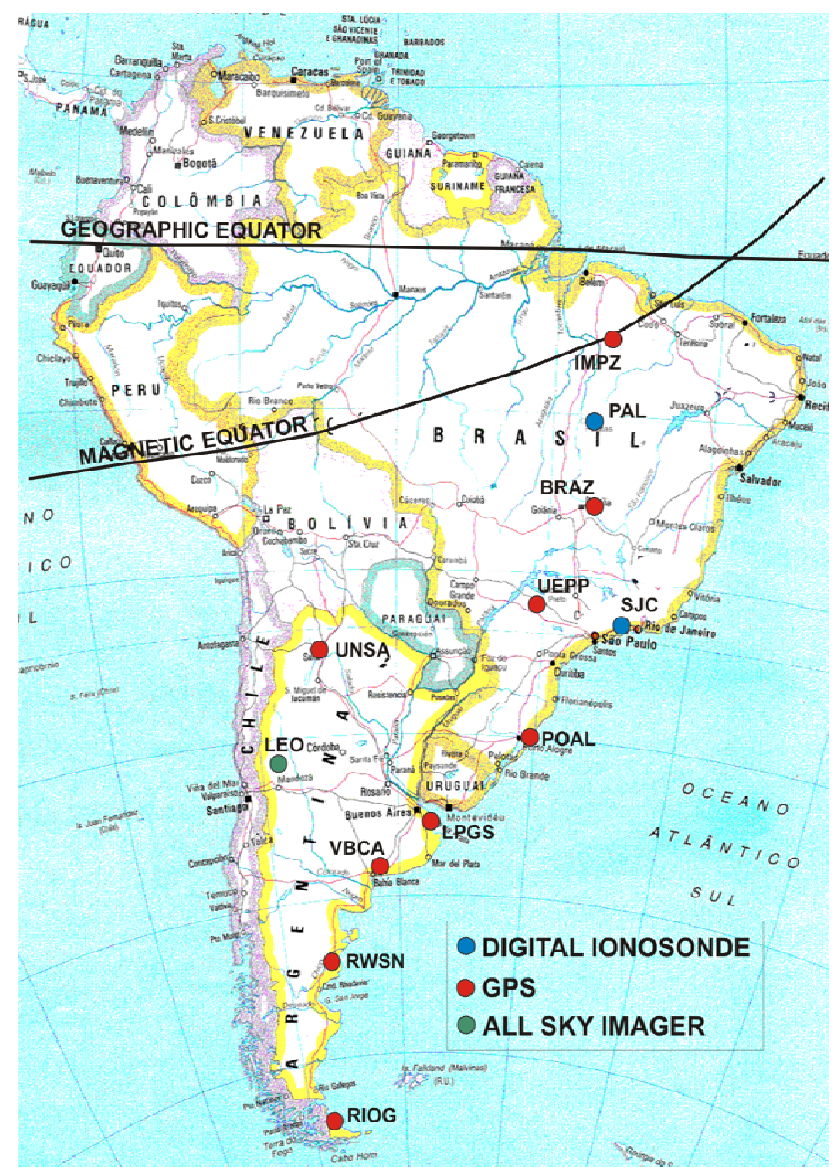

Fig. 2. Map showing the locations of the ionospheric sounding, allsky nightglow imaging and GPS stations.

ionospheric response during geomagnetic storms: electric fields (solar wind- magnetosphere dynamo (e.g., Senior and Blanc, 1984; Spiro et al., 1988; and Tsurutani et al., 2008), and ionospheric disturbance dynamo (e.g., Blanc and Richmond, 1980), winds (transport of energy from high latitude (Joule heating or Lorentz forcing) in the form of traveling atmospheric disturbances (TADs) (e.g., Buonosanto, 1999; Nicolls et al., 2004), and composition changes $\left(\mathrm{O} / \mathrm{N}_{2}\right.$ ratio) (e.g., Zhang et al., 2003; Meier et al., 2005).

Figure 1 shows the $K_{p}, D_{s t}$, and AE geomagnetic indices observed during the period 29-31 October 2003. Considering an intense geomagnetic storm with $\left|D_{s t \max }\right|>250 \mathrm{nT}$ as a superstorm, two superstorms were observed during the period 29-30 October. There was a storm sudden commencement (SSC) at 06:11 UT on 29 November and a sudden impulse at 10:29 on 30 October. The $\left|D_{s t \max }\right|$ reached $363 \mathrm{nT}$ at 01:00 UT and $401 \mathrm{nT}$ at 23:00 UT on 30 October. The AE index variations show that this index attained several times values greater that $2500 \mathrm{nT}$ during the period 29-30 October.

The principal objectives of this paper have been to use the multi-instrument, multi-site optical/radio techniques 


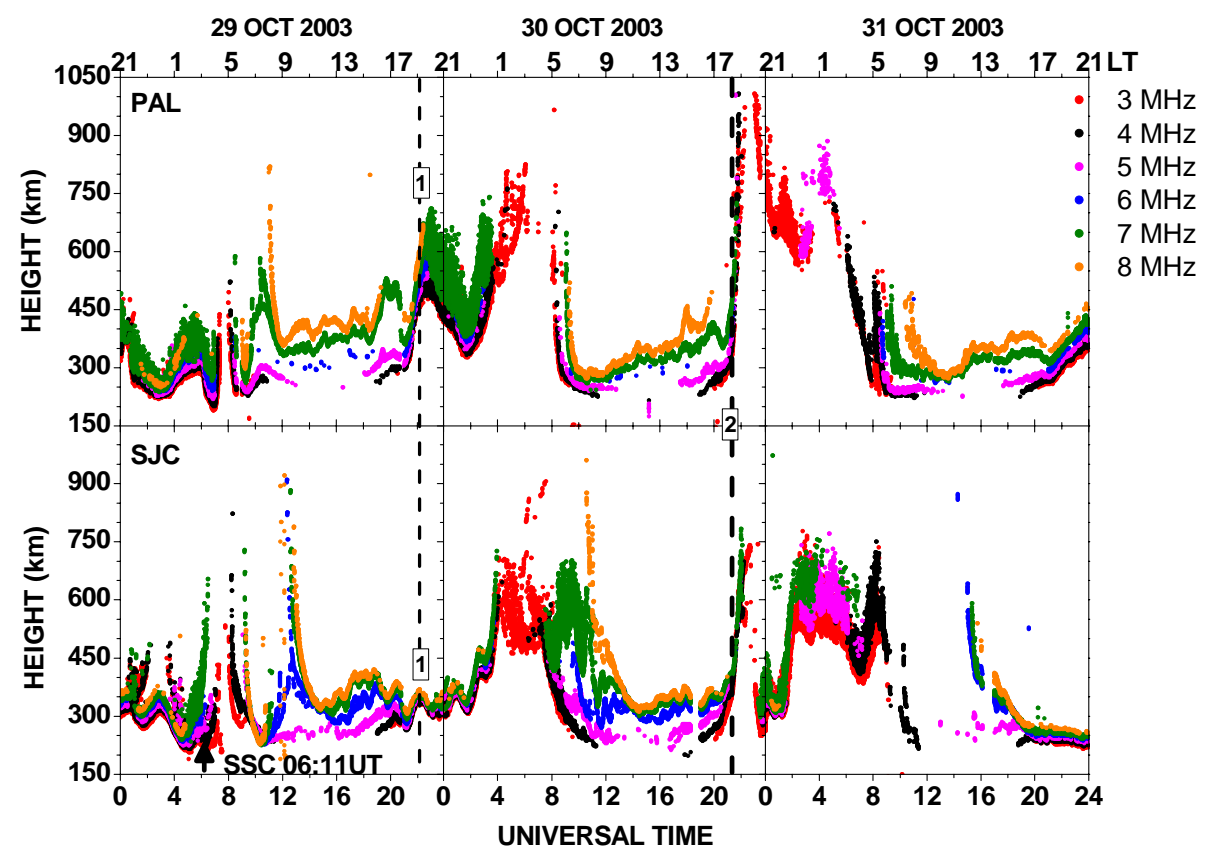

Fig. 3. Plots of the virtual height variations for six different frequencies (iso-frequency plots) observed at Palmas (top panel) and Sao Jose dos Campos (bottom panel), Brazil, for the UT days 29 to 31 October 2003. Also, the local time is shown at the top.

observation to investigate the generation and latitudinal extent of equatorial ionospheric irregularities, also known as equatorial spread-F (ESF), and ionospheric dynamics in the South American sector during the superstorms on 29 and 30 October. Of the late, the earlier view that a geomagnetic storm suppresses the generation of the ESF is no longer valid (e.g., Tsurutani et al., 2004; Becker-Guedes et al., 2004; Martinis et al., 2005; Chakrabarty et al., 2006). However, several investigators have reported ESF in post midnight period during geomagnetic disturbances earlier. Statistical analysis of ESF on geomagnetic quiet and disturbed days showed that ESF in the post midnight period could be more on disturbed days during low sunspot years and J-months (northern summer months) (Chandra and Rastogi, 1972). Rastogi et al. (1978) showed increase of ESF on disturbed days or high Kp days at Huancayo, Peru, in post midnight periods. A case study carried out by Rastogi and Woodman (1978) showed how ESF was triggered in the post midnight period due to sudden changes in IMF when F-region rises fast. Figure 2 and Table 1 show details of the ionospheric sounding, all-sky imaging, and GPS stations used in the present investigation. Also, some details of the apex point (dip latitude $=0$ ) for different observing stations are given in Table 1. The apex height was calculated by tracing the geomagnetic field lines passing through the observed irregularities (altitude $300 \mathrm{~km}$ ) using the International Geomagnetic Reference Field 2000 model (Mandea and Macmillan, 2000).

\section{Observations}

In this paper, several F-region observations carried out in the South American sector during the period 27-31 October 2003 are presented and discussed. Figure 3 shows the isofrequency plots (virtual height variations of the ionospheric F-region at six frequencies obtained every $100 \mathrm{~s}$ ) from ionospheric sounding observations using the Canadian Advanced Digital Ionosonde (CADI) (Grant et al., 1995; Abalde et al., 2001) operational at Palmas (10.2 S, 48.2 W; dip lat. 5.3 S; hereafter referred as PAL) and Sao Jose dos Campos (23.2 S, $45.9 \mathrm{~W}$; dip lat. 17.2 S; hereafter referred as SJC), Brazil, on 29 and 30 October 2003. Figure 4 shows the sequences of the all-sky nightglow images (OI $630 \mathrm{~nm}$ and OI $777.4 \mathrm{~nm}$ emissions) obtained at El Leoncito (31.8 S, $69.3 \mathrm{~W}$; dip lat. 17.0 S), Argentina (Martinis et al., 2006), on the night of 28-29 October 2003, a geomagnetically quiet night (ionospheric irregularities or plasma bubbles were observed between about 01:10 to 05:15 UT). Figure 5 shows the sequences of the all-sky nightglow images (OI $630 \mathrm{~nm}$ and OI $777.4 \mathrm{~nm}$ emissions) obtained at El Leoncito on the night of 29-30 October 2003, a geomagnetically disturbed night (ionospheric irregularities or plasma bubbles were observed between about 02:15 to 04:45 UT). It should be mentioned that due to the moon phase no airglow imaging observations were possible during the earlier parts of the nights on 2829 and 29-30 October. Figures 6 and 7 show the variations of the ion density observed from the DMSP F13, F14 and F15 satellites orbiting at an altitude of about $840 \mathrm{~km}$, passing through the South American sector, on the nights of 
Table 1. Locations of the digital ionospheric (DI) sounding, all-sky airglow (OI 630 and $777.4 \mathrm{~nm}$ emissions) imaging and GPS stations. Also, apex point (dip latitude $=0$ ) details are given.

\begin{tabular}{|c|c|c|c|c|c|c|c|c|}
\hline $\begin{array}{l}\text { Location } \\
\text { Symbol } \\
\text { (Network) }\end{array}$ & Obs. & $\begin{array}{l}\text { Geog. } \\
\text { Lat. }\end{array}$ & $\begin{array}{l}\text { Geog. } \\
\text { Long. }\end{array}$ & $\begin{array}{l}\text { Dip } \\
\text { Lat. }\end{array}$ & Declina & $\begin{array}{l}\text { Local Time } \\
\text { (LT) }\end{array}$ & $\begin{array}{l}\text { Apex Point } \\
\text { Altitude }\end{array}$ & Declina \\
\hline $\begin{array}{l}\text { Imperatriz } \\
\text { IMPZ } \\
\text { (RBMC) }\end{array}$ & GPS & $05.5^{\circ} \mathrm{S}$ & $47.5^{\circ} \mathrm{W}$ & $1.5^{\circ} \mathrm{S}$ & $18.9^{\circ} \mathrm{W}$ & $\mathrm{LT}=\mathrm{UT}-3 \mathrm{~h}$ & $308.2 \mathrm{~km}$ & $18.6^{\circ} \mathrm{W}$ \\
\hline $\begin{array}{l}\text { Palmas } \\
\text { PAL } \\
\text { (UNIVAP) }\end{array}$ & DI & $10.2^{\circ} \mathrm{S}$ & $48.2^{\circ} \mathrm{W}$ & $5.3^{\circ} \mathrm{S}$ & $18.8^{\circ} \mathrm{W}$ & $\mathrm{LT}=\mathrm{UT}-3 \mathrm{~h}$ & $366.7 \mathrm{~km}$ & $17.8^{\circ} \mathrm{W}$ \\
\hline $\begin{array}{l}\text { Brasilia } \\
\text { BRAZ } \\
\text { (RBMC) }\end{array}$ & GPS & $15.9^{\circ} \mathrm{S}$ & $47.9^{\circ} \mathrm{W}$ & $10.3^{\circ} \mathrm{S}$ & $18.6^{\circ} \mathrm{W}$ & $\mathrm{LT}=\mathrm{UT}-3 \mathrm{~h}$ & $537.8 \mathrm{~km}$ & $16.8^{\circ} \mathrm{W}$ \\
\hline $\begin{array}{l}\text { Presidente Prudente } \\
\text { UEPP } \\
\text { (RBMC) }\end{array}$ & GPS & $22.3^{\circ} \mathrm{S}$ & $51.4^{\circ} \mathrm{W}$ & $13.8^{\circ} \mathrm{S}$ & $15.7^{\circ} \mathrm{W}$ & $\mathrm{LT}=\mathrm{UT}-3 \mathrm{~h}$ & $749.6 \mathrm{~km}$ & $14.1^{\circ} \mathrm{W}$ \\
\hline $\begin{array}{l}\text { Sao Jose dos Campos } \\
\text { SJC } \\
\text { (UNIVAP) }\end{array}$ & DI & $23.2^{\circ} \mathrm{S}$ & $45.9^{\circ} \mathrm{W}$ & $17.2^{\circ} \mathrm{S}$ & $20.2^{\circ} \mathrm{W}$ & $\mathrm{LT}=\mathrm{UT}-3 \mathrm{~h}$ & $973.7 \mathrm{~km}$ & $15.4^{\circ} \mathrm{W}$ \\
\hline $\begin{array}{l}\text { Salta } \\
\text { UNSA } \\
\text { (SIRGAS) }\end{array}$ & GPS & $24.7^{\circ} \mathrm{S}$ & $65.4^{\circ} \mathrm{W}$ & $11.6^{\circ} \mathrm{S}$ & $4.5^{\circ} \mathrm{W}$ & $\mathrm{LT}=\mathrm{UT}-4 \mathrm{~h}$ & $630.0 \mathrm{~km}$ & $6.8^{\circ} \mathrm{W}$ \\
\hline $\begin{array}{l}\text { Porto Alegre } \\
\text { POAL } \\
\text { (RBMC) }\end{array}$ & GPS & $30.1^{\circ} \mathrm{S}$ & $51.1^{\circ} \mathrm{W}$ & $19.8^{\circ} \mathrm{S}$ & $13.5^{\circ} \mathrm{W}$ & $\mathrm{LT}=\mathrm{UT}-3 \mathrm{~h}$ & $1311.7 \mathrm{~km}$ & $12.2^{\circ} \mathrm{W}$ \\
\hline $\begin{array}{l}\text { El Leoncito } \\
\text { LEO } \\
\text { (BU) }\end{array}$ & IMAGER & $31.8^{\circ} \mathrm{S}$ & $69.3^{\circ} \mathrm{W}$ & $17.0^{\circ} \mathrm{S}$ & $1.6^{\circ} \mathrm{E}$ & $\mathrm{LT}=\mathrm{UT}-4 \mathrm{~h}$ & $1070.4 \mathrm{~km}$ & $4.3^{\circ} \mathrm{W}$ \\
\hline $\begin{array}{l}\text { La Plata } \\
\text { LPGS } \\
\text { (SIRGAS) }\end{array}$ & GPS & $34.9^{\circ} \mathrm{S}$ & $57.9^{\circ} \mathrm{W}$ & $20.9^{\circ} \mathrm{S}$ & $6.3^{\circ} \mathrm{W}$ & $\mathrm{LT}=\mathrm{UT}-4 \mathrm{~h}$ & $1554.6 \mathrm{~km}$ & $8.9^{\circ} \mathrm{W}$ \\
\hline $\begin{array}{l}\text { Bahia Blanca } \\
\text { VBCA } \\
\text { (SIRGAS) }\end{array}$ & GPS & $38.7^{\circ} \mathrm{S}$ & $62.3^{\circ} \mathrm{W}$ & $22.6^{\circ} \mathrm{S}$ & $0.7^{\circ} \mathrm{W}$ & $\mathrm{LT}=\mathrm{UT}-4 \mathrm{~h}$ & $1887.9 \mathrm{~km}$ & $6.8^{\circ} \mathrm{W}$ \\
\hline $\begin{array}{l}\text { Rawson } \\
\text { RWSN } \\
\text { (SIRGAS) }\end{array}$ & GPS & $43.3^{\circ} \mathrm{S}$ & $65.1^{\circ} \mathrm{W}$ & $25.3^{\circ} \mathrm{S}$ & $4.0^{\circ} \mathrm{E}$ & $\mathrm{LT}=\mathrm{UT}-4 \mathrm{~h}$ & $2499.4 \mathrm{~km}$ & $5.4^{\circ} \mathrm{W}$ \\
\hline $\begin{array}{l}\text { Rio Grande } \\
\text { RIOG } \\
\text { (SIRGAS) }\end{array}$ & GPS & $53.8^{\circ} \mathrm{S}$ & $67.8^{\circ} \mathrm{W}$ & $31.8^{\circ} \mathrm{S}$ & $11.7^{\circ} \mathrm{E}$ & $\mathrm{LT}=\mathrm{UT}-4 \mathrm{~h}$ & $4815.7 \mathrm{~km}$ & $4.0^{\circ} \mathrm{W}$ \\
\hline
\end{tabular}

29-30 October 2003 and 30 October 2003 (UT). Figure 8 shows the time rate change of TEC (TECU/min), also known as phase fluctuations (Aarons et al., 1996), using data from different GPS stations. It should be pointed out that the phase fluctuations represent ionospheric irregularities of the order of kilometers (Aarons et al., 1997). Figure 9 shows the plot of the average vertical total electron content (VTEC) obtained using global positioning system (GPS) satellites (above 30-degree elevation) at several GPS receiving stations in the South American sector. The VTEC for calculating the average used the algorithm presented by Brunini et al. (2003). The red line is the day's data and the green line is for a quiet day before the storm-time for a comparison. Figure 10 shows eight "Global Ionospheric TEC (total electron content)" maps (Mannucci et al., 1998) from about 100 GPS receiver stations obtained between 29-31 October. Figure 11 shows six GPS-based TEC maps (obtained from the website http://cdaweb.gsfc.nasa.gov./sp_phys/) from the global GPS network for the same UT on geomagnetically quiet days (2728 October; left column) and geomagnetically disturbed or recovery days (29-31 October; right column). The brief descriptions of the figures given in this section are discussed with more detail in the next section. 
El Leoncito $630.0 \mathrm{~nm}, 29$ October 2003
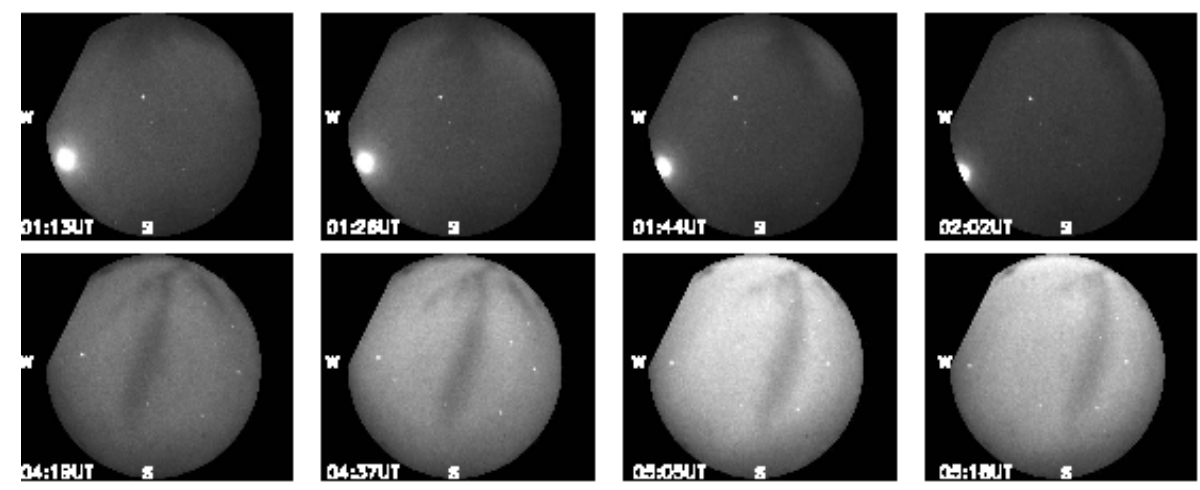

El Leoncito $777.4 \mathrm{~nm}, 29$ October 2003
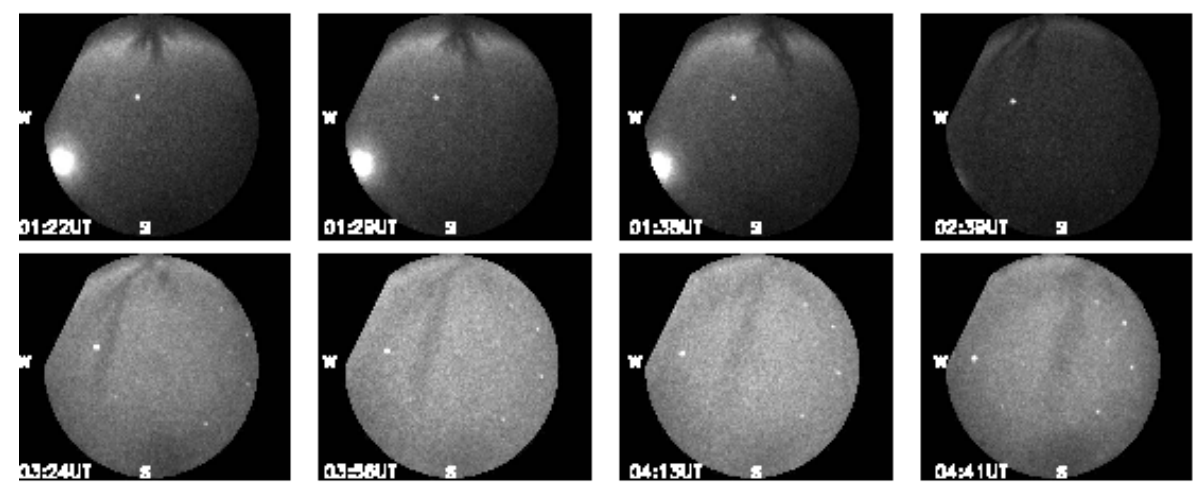

Fig. 4. A sequence of the F-region all-sky nightglow images obtained at El Leoncito, Argentina, on the night of 28-29 October 2003 (quiet night). The top panel shows the OI $630.0 \mathrm{~nm}$ emission images and the bottom panel shows the OI $777.4 \mathrm{~nm}$ emission images.

\section{Results and discussion}

An analysis of the ionospheric sounding, all-sky F-region nightglow imaging, and GPS observations obtained at several stations in the South American sector during the super geomagnetic storms on 29 and 30 October 2003 are presented and discussed. After the SSCs on 29 and 30 October, unusual uplifting of the F-layer, due to penetration electric fields, in the equatorial region during the pre-reversal enhancement periods on both days were observed (points 1 and 2; Fig. 3). As described by VanZandt et al. (1971; see also Sastri et al., 2002) the most direct and easily observed effects of $\boldsymbol{E} \times \boldsymbol{B}$ drift are changes in the height of the F-region. It should be mentioned that the geomagnetic $D_{s t}$ index was decreasing rapidly during these periods and the eastward penetration electric field was particularly enhanced due to the global electric field. As mentioned by Basu et al. (2007), in the dusk sector, the eastward penetration electric field, associated with rapid $D_{s t}$ decrease, adds to the post-sunset eastward E-field because of the F-region dynamo, and this enhanced E-field at dusk causes a rapid uplift of the ionosphere and sets off plasma instabilities.
On the evening of 30 October, the uplifting was much stronger and was observed both at PAL and at SJC. At PAL, the uplifting was at a rate of about $170 \mathrm{~m} / \mathrm{s}$. As described by Huang (2008), the enhancement of the upward plasma drift driven by eastward penetration electric field was measured by the DMSP satellite. The increase of the vertical drift is about $180 \mathrm{~m} / \mathrm{s}$, consistent with the uplifting of $170 \mathrm{~m} / \mathrm{s}$ estimated from the PAL digital ionosonde data. The unusual lifting of the F-layer in the equatorial region on 29 and 30 October during the pre-reversal period resulted in the generation of equatorial ionospheric irregularities and plasma bubbles in the Brazilian sector (Figs. 3 and 8). Also, Fig. 8 shows that the Argentinean stations (UNSA, LPGS, VBCA and RWSN), with geomagnetic field lines west of the Brazilian sector (see Table 1), have strong phase fluctuations close to the pre-reversal enhancement period (after local sunset) indicating the presence of equatorial ionospheric irregularities and plasma bubbles on the nights of 29-30 (ionospheric irregularities or plasma bubbles in the South American sector were observed between about 22:00 to 08:00 UT; see Fig. 8) and 30-31 October (ionospheric irregularities or plasma bubbles in the South American sector were observed between about 21:00 to 04:00 UT; see Fig. 8). Since the investigation 
El Leoncito $630.0 \mathrm{~nm}, 30$ October 2003
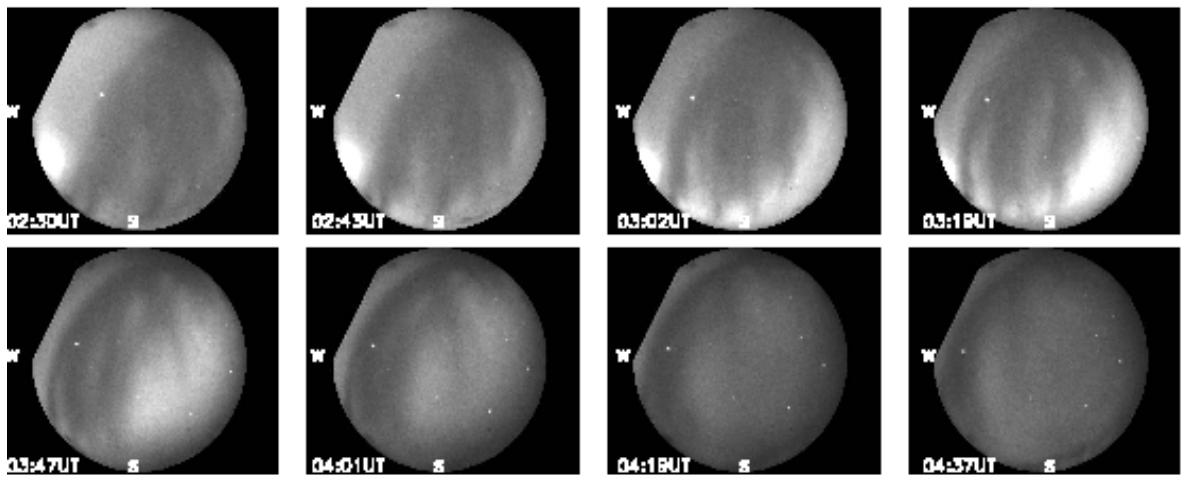

El Leoncito $777.4 \mathrm{~nm}, 30$ October 2003
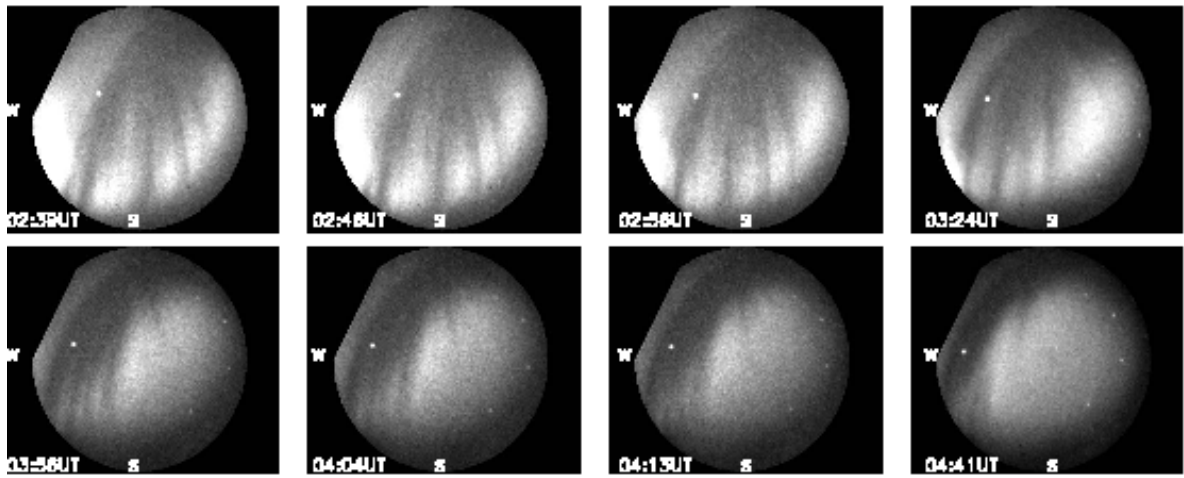

Fig. 5. A sequence of the F-region all-sky nightglow images obtained at El Leoncito, Argentina, on the night of 29-30 October 2003 (geomagnetically disturbed). The top panel shows the OI $630.0 \mathrm{~nm}$ emission images and the bottom panel shows the OI $777.4 \mathrm{~nm}$ emission images.

of ionospheric irregularities up to RWSN is based on phase fluctuations (Fig. 8), the scale size of the ionospheric irregularities is of the order of kilometers (Aarons et al., 1997). A perusal of Table 1 indicates that observed ionospheric irregularities or plasma bubbles at the Argentinean station RWSN will map at the magnetic equator at an altitude of about $2500 \mathrm{~km}$. This is in conformity with Sahai et al. (1994), where it was indicated that the plasma bubbles attain very high apex altitudes. Figures 4 and 5 showing the F-region all-sky imaging observations also indicate that the observed plasma bubbles are well within the observational field of view on the geomagnetically quiet night of 28-29 October, whereas on the night of 29-30 October with geomagnetic disturbance, the observed plasma bubbles cut across the field of view. These observations are also in line with Sahai et al. (1994). On the nights before the geomagnetic storms viz., 26-27 (ionospheric irregularities or plasma bubbles in the Brazilian sector were observed between about 00:00 to 04:00 UT; see Fig. 8), 27-28 (ionospheric irregularities or plasma bubbles in the South American sector were observed between about 23:00 to 06:00 UT; see Fig. 8), and 28-29 October (ionospheric irregularities or plasma bubbles in the
South American sector were observed between about 22:00 to 06:00 UT; see Fig. 8). Figure 8 shows that the ionospheric irregularities extend to POAL on the night of 27-28 October but is limited up to UEPP on the night of 26-27 October. The ionospheric sounding observations at PAL and SJC on these nights indicate this could be associated with the day-to-day variability in the evening height rise of the F-region.

The Argentinean station RIOG (dip lat. 31.8; geomag. lat. 43.6 S), a high mid-latitude station, shows very low VTEC (see Fig. 9) with very low VTEC fluctuations close to the sunset time on the nights of 29-30 and 30-31 October but accompanied with very large phase fluctuations after about 22:00 UT on both the nights. The large phase fluctuations observed are associated with mid-latitude spread-F during geomagnetic activity as described by Bowman (1984). The station RIOG could be within the sub-auroral polarization streams (SAPS) (Huang and Foster, 2007) region or even southward of the SAPS region during the intense geomagnetic storms. When the station is in or close to the SAPS region, the VTEC must be very low. Also, ionospheric sounding observations at Port Stanley (51.6 S, 57.9 W), close to Rio Grande, show the presence of spread F on the ionograms 

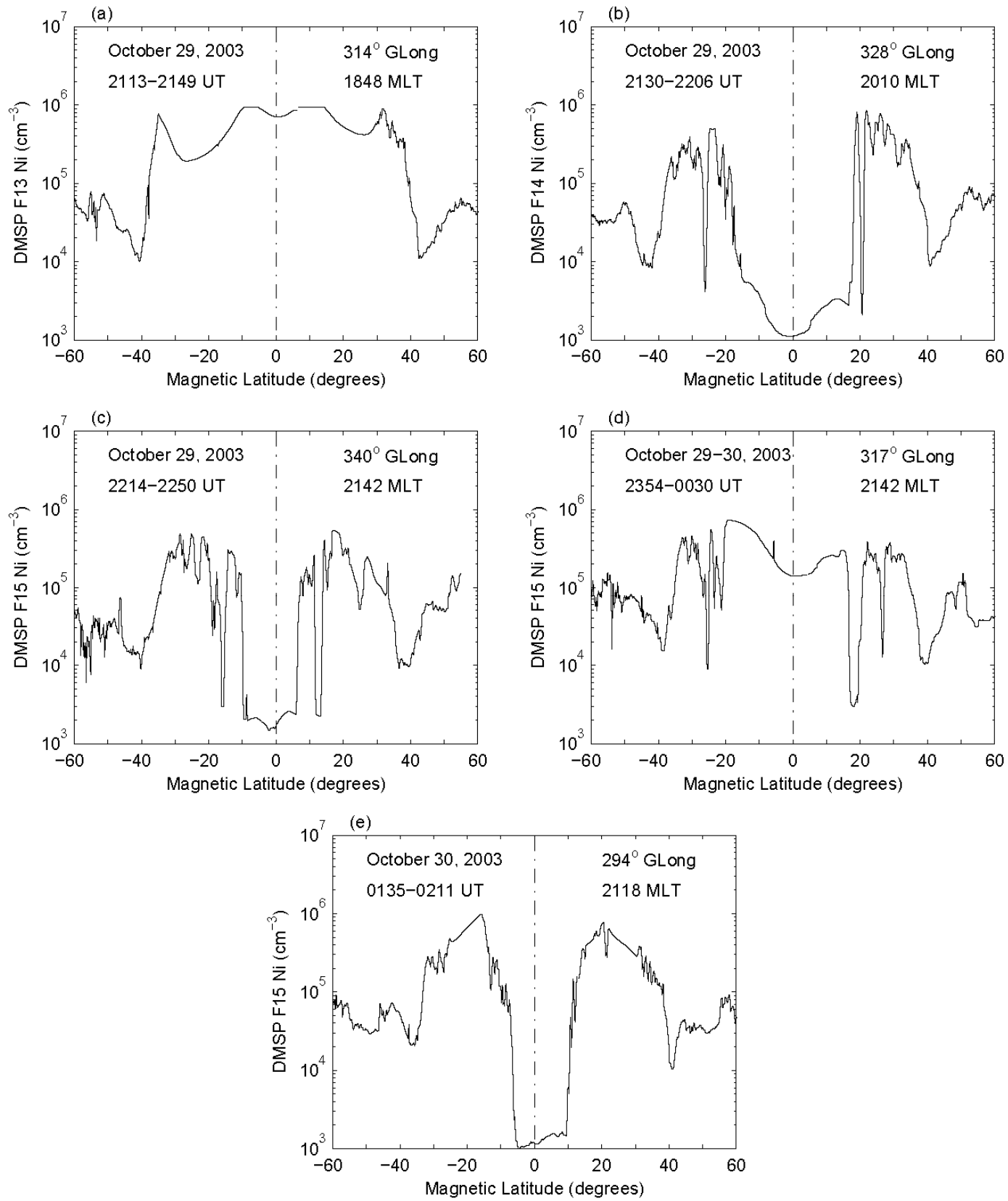

Fig. 6. Variations of the ion density observed from the DMSP F13, F14 and F15 satellites orbiting at an altitude of about $840 \mathrm{~km}$ in the South American sector on the night of 29-30 October 2003 (UT).

on both the nights of $29-30$ and 30-31 October. No spread-F was observed at Port Stanley on the night of 28-29 October (a geomagnetically quiet night). It should be pointed out that because the station Rio Grande could be within in the SAPS region, the ionospheric behavior at this station is very different from other stations.

Figure 4 shows the sequences of the all-sky nightglow images from the F-region OI $630 \mathrm{~nm}$ and OI 777.4 emissions, obtained at El Leoncito, Argentina (Martinis et al., 2006), on the night of 28-29 October 2003 (a geomagnet- ically quiet night). Figure 5 shows similar sequences of the all-sky nightglow images (OI $630 \mathrm{~nm}$ and OI $777.4 \mathrm{~nm}$ emissions) obtained at El Leoncito on the night of 29-30 October 2003 (a geomagnetically disturbed night). Also, the ray-like structures seen clearly with the $777.4 \mathrm{~nm}$ emission are due to very small life time of this emission as described in detail by Abalde et al. (2001). A perusal of the OI $630 \mathrm{~nm}$ images shown in Fig. 4 clearly indicates that between 04:06 UT (00:06 LT) and 05:36 UT (01:36 LT) plasma bubbles are drifting toward east on this geomagnetically quiet 

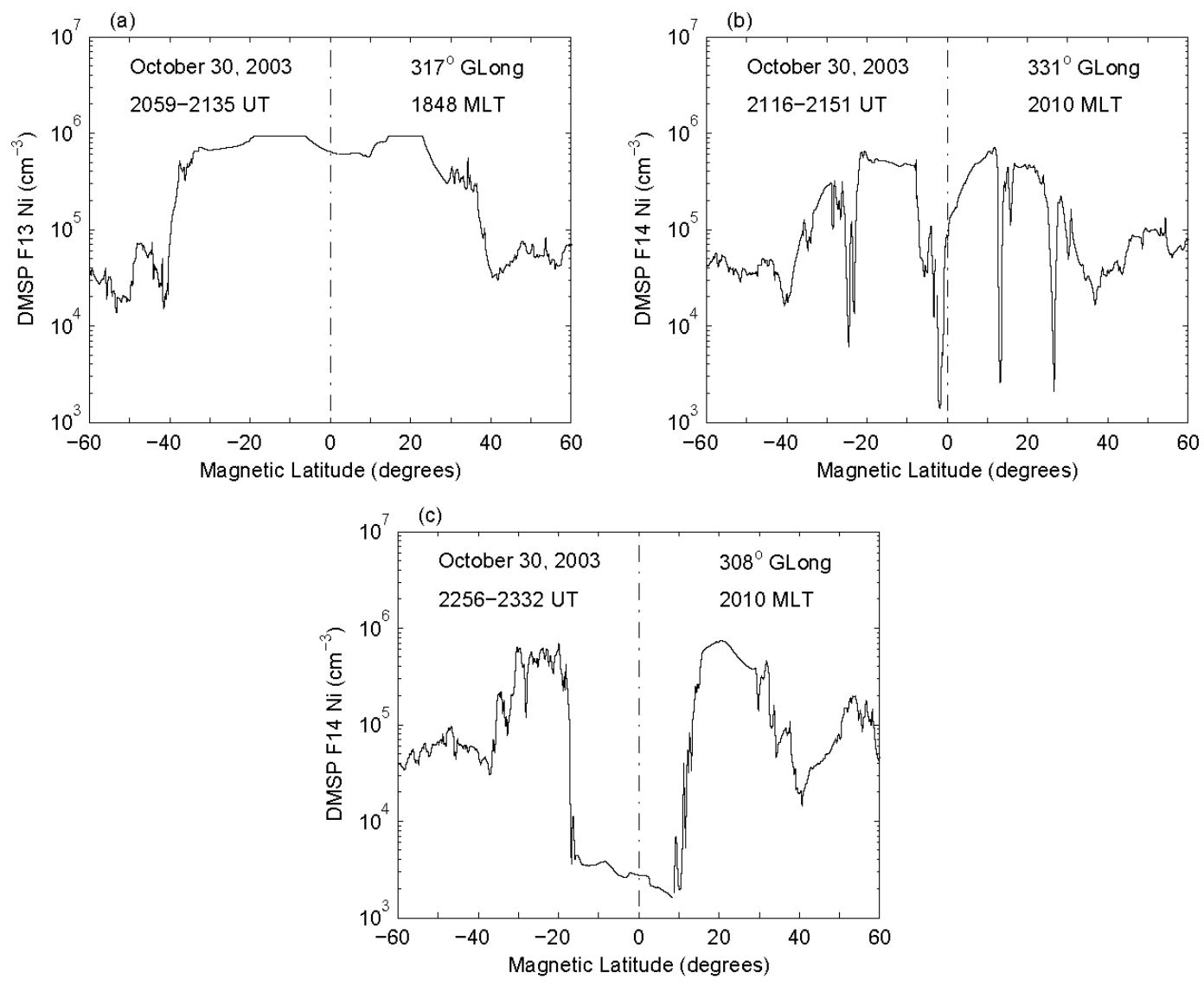

Fig. 7. Variations of the ion density observed from the DMSP F13 and F14 satellites orbiting at an altitude of about $840 \mathrm{~km}$ in the South American sector on the night of 30 October 2003 (UT).

night. At 05:05 UT (01:05 LT) the OI $630 \mathrm{~nm}$ image shows strong increase in intensity nearly in the full field of view indicating that possibly the F-layer came down at this time. The all-sky imaging observations of the OI $777.4 \mathrm{~nm}$ and OI $630.0 \mathrm{~nm}$ emissions on the night of 28-29 October (quiet night) show ionospheric plasma bubbles drifting to east (normal), whereas on the geomagnetically disturbed night of 2930 October, both the emissions show that the plasma bubbles drift towards west (not normal). The present results during the geomagnetic disturbance are similar to the observations in the Brazilian sector reported by Abdu et al. (2003) during the major magnetic storm of 26 August 1998. As mentioned by Abdu et al. (2003) the results point out to the dominant role of a disturbance dynamo associated westward thermospheric wind to maintain the plasma irregularity drift increasingly westward going into postmidnight local time.

Figures 6 and 7 show the variations of the ion density observed from the DMSP F13, F14 and F15 satellites (e.g. Basu et al., 2005, 2007; Huang et al., 2007; Huang, 2008) orbiting at an altitude of about $840 \mathrm{~km}$, passing through the South American sector, on the nights of 29-30 October 2003 and 30 October 2003 (UT). The DMSP satellite moves from east to west and from the Southern to Northern Hemisphere in the evening sector. The time given in Fig. 6a, such as 21:13-21:49 UT, is the time interval during which the satellite moves from -60 to 60 degrees magnetic latitudes. Again, in Fig. $6 a, 314^{\circ}$ Glong refers to the longitude for the magnetic equator crossing and 18:48 MLT refers to the magnetic local time at the magnetic equator. This MLT should be very close to LT in the equatorial and low latitude regions. All the plots in Figs. 6 and 7 show a dip in ion density close to 40 degrees north 40 degrees south magnetic latitude during this geomagnetically disturbed period. This possibly indicates that the plasmapause moved to lower magnetic latitudes during this intense geomagnetic disturbance (Huang and Foster, 2007; Horvath and Lovell, 2008). The low density region at $\sim 40$ magnetic latitudes is the region of the sub-auroral polarization streams (SAPS), and this region coincides with the mid-latitude trough during the intense geomagnetic storms. Figures 6 and 7 show large equatorial plasma depletions during several passages. These have been referred to as storminduced big bubbles (SIBBs) (Kil et al., 2006).

Mendillo (2006) has recently reviewed storms in the ionosphere, patterns and processes for total electron content. Figure 9 shows average GPS-TEC observations (red lines) and indicate that several hours after the SSC on 29 October, 


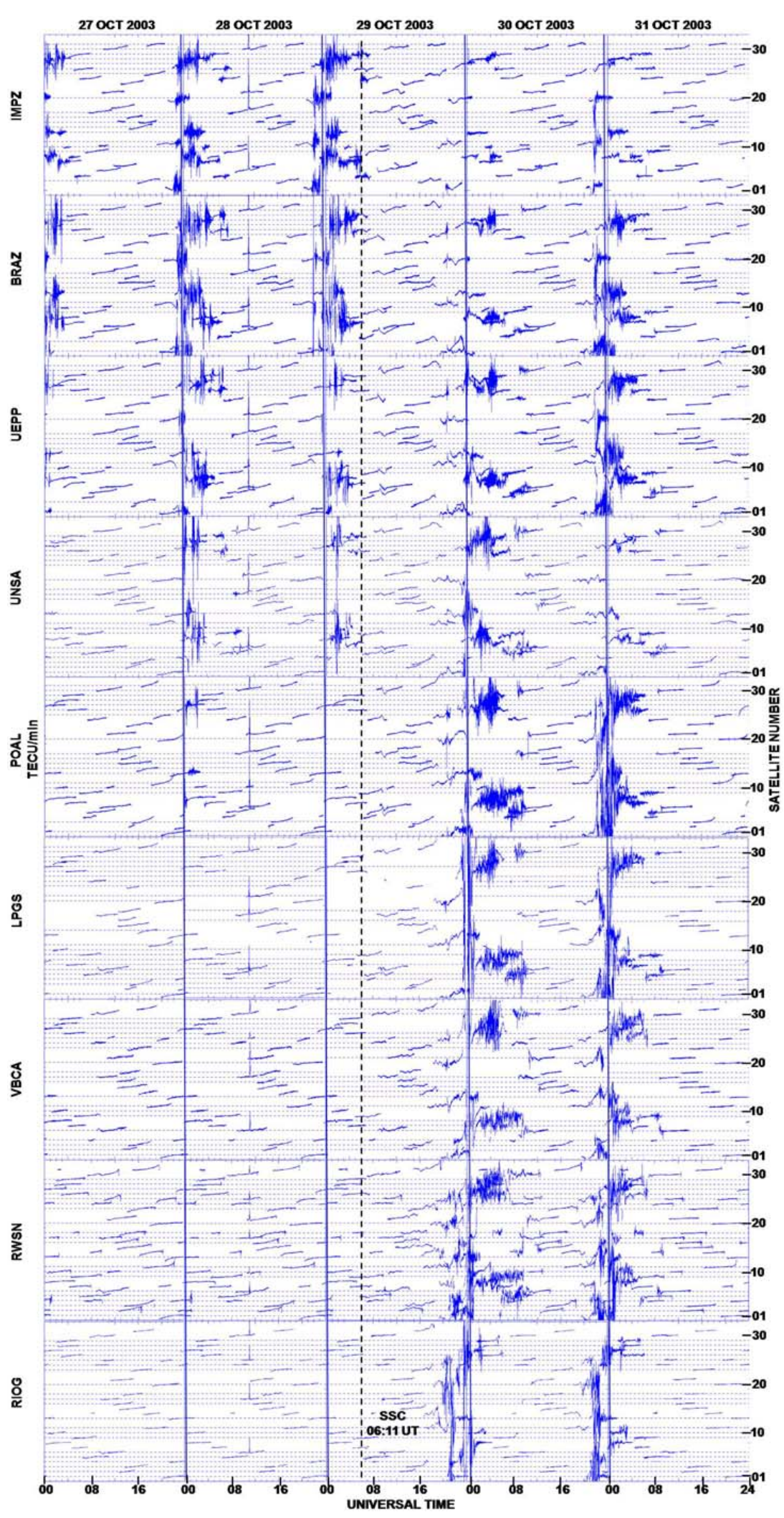

Fig. 8. The time rate change of TEC (TECU/min) measured at different GPS stations. 


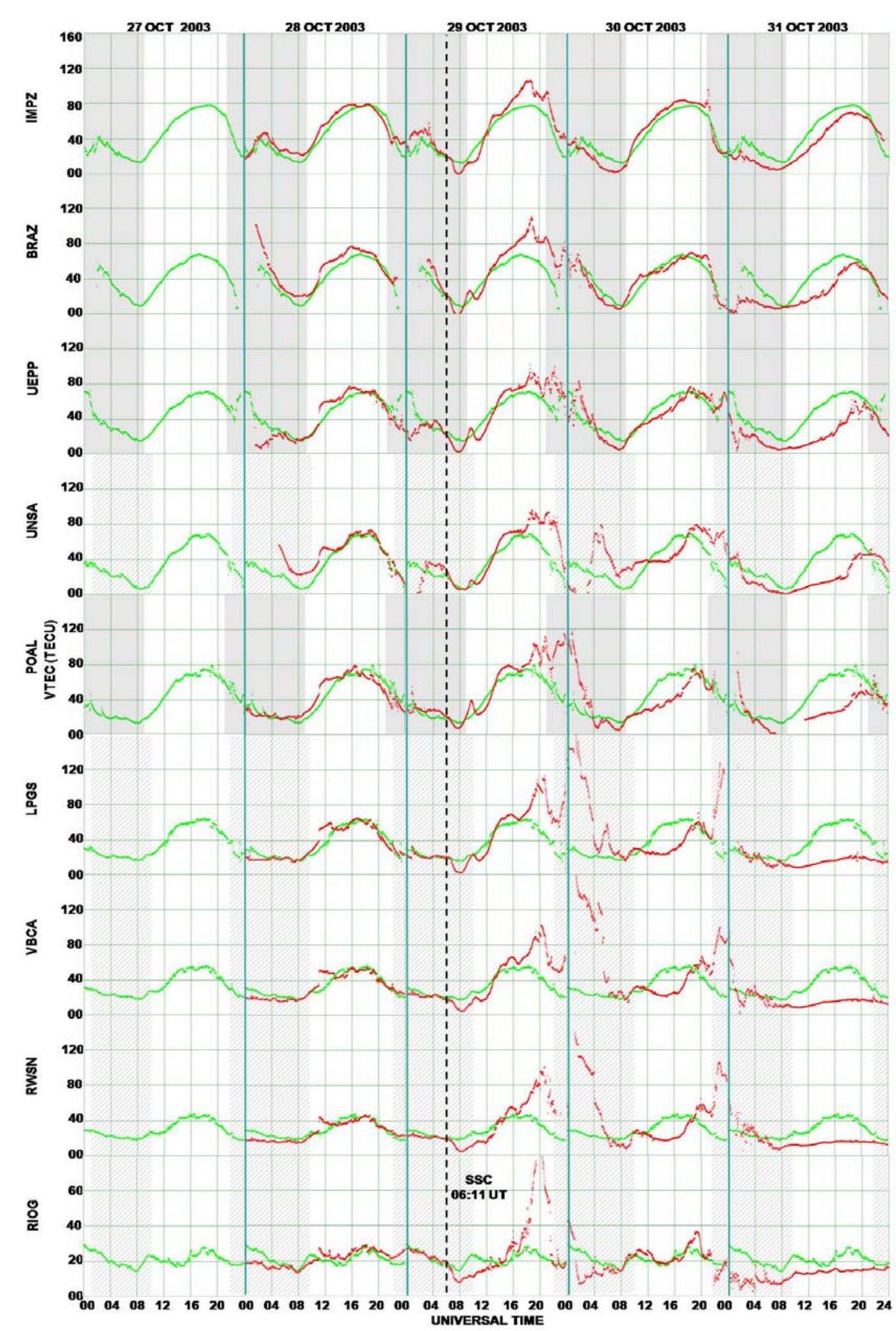

Fig. 9. The average vertical electron content (VTEC) measured using different satellites (above 30 degrees elevation) at several GPS stations in the South American sector. The red line is the day's data and the green line is for a quiet day before the storm.

the TEC variations undergo drastic enhancements. During the daytime, associated with heating in the southern auroral zone, large enhancement is observed at RIOG, propagating to lower latitudes up to LPGS on 29 October. Similar but smaller enhancements are seen during the daytime on 30 October extending to POAL. However, the enhancements on 30 October are preceded by negative storm phase from RWSN to POAL. Again, negative storm phase starting after midnight on 31 October (recovery phase) and continuing throughout the daytime is seen from IMPZ to RIOG. The negative phase of the storm is due to composition $\left(\mathrm{O} / \mathrm{N}_{2}\right.$ ratio) changes. During the pre-reversal time on 29 and 30 October, the geomagnetic storm electric fields cause the crests of the Appleton anomaly to move much further south (Mannucci et 
(a)

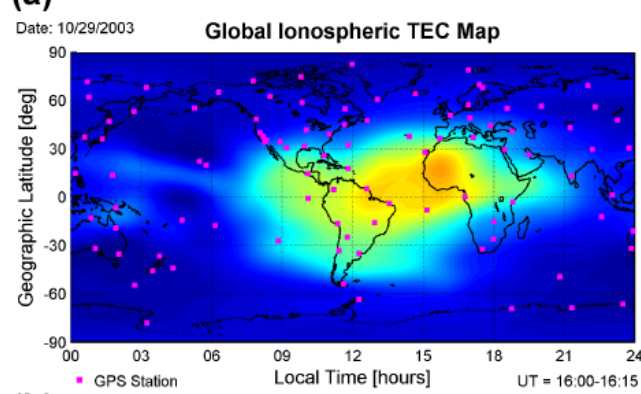

(b)

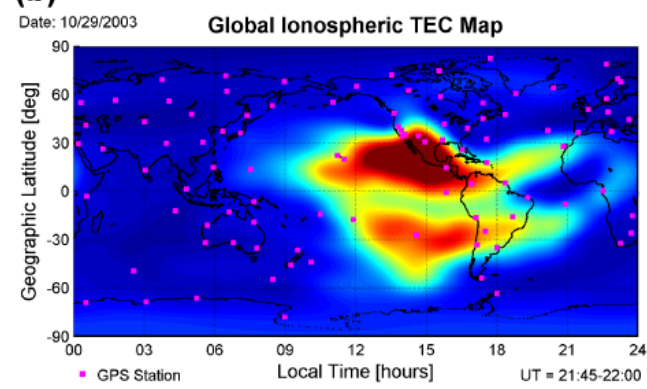

(c)

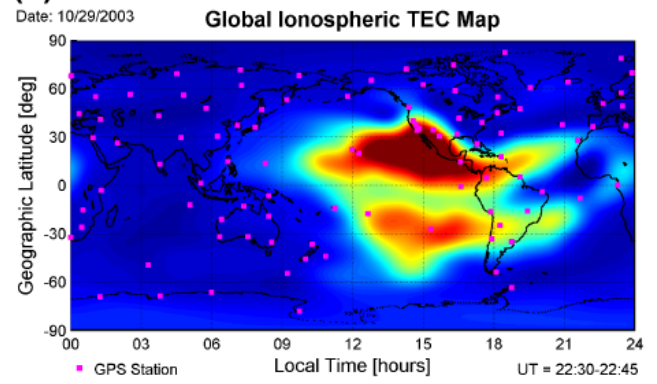

(d)

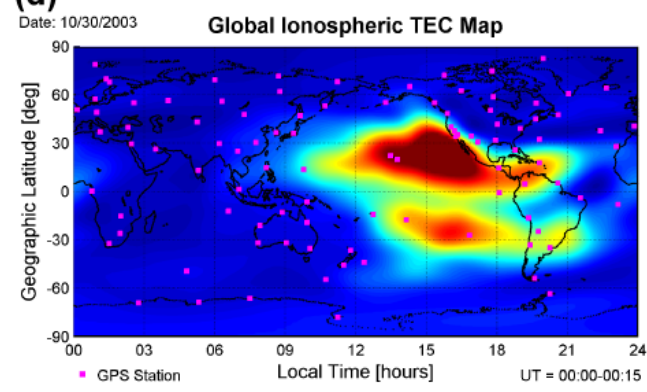

(e)

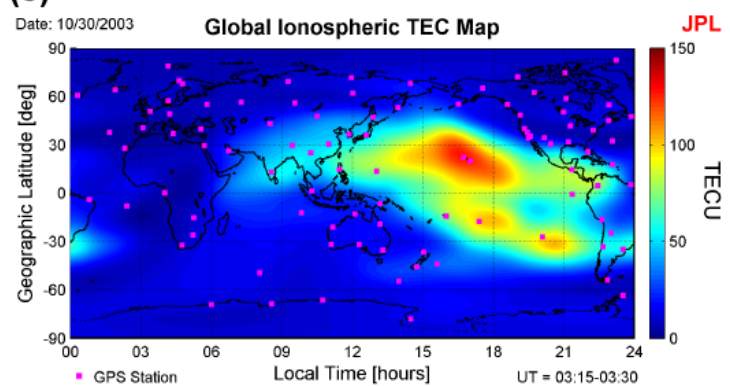

(f)

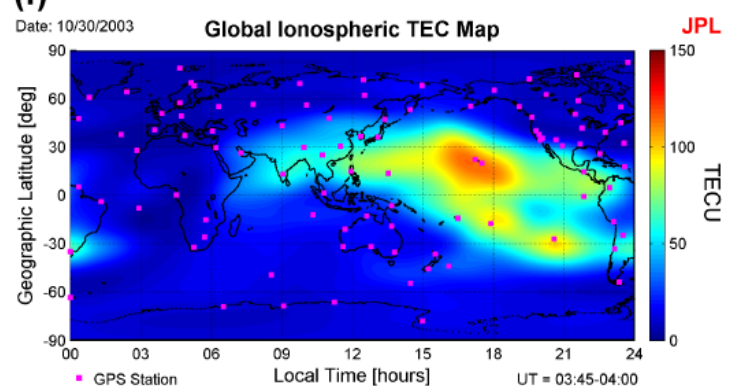

(g)

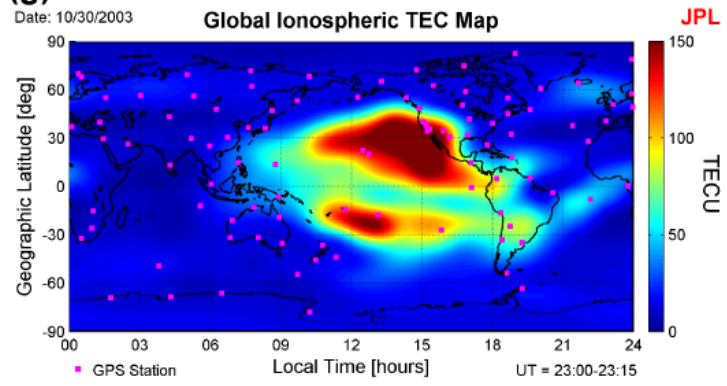

(h)

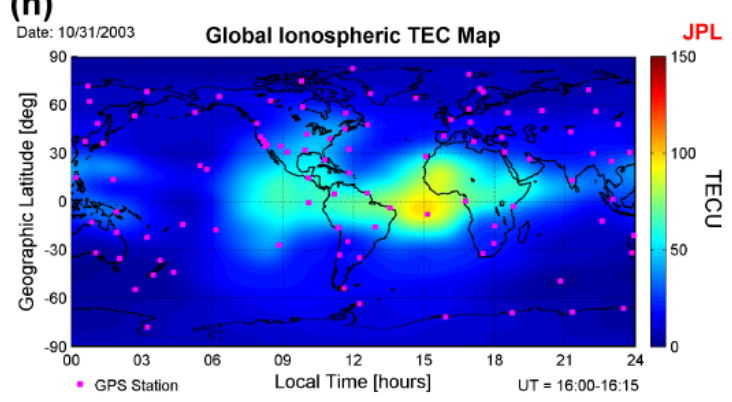

Fig. 10. Eight global TEC maps, with 15-min resolution, produced at the Jet Propulsion Laboratory using GPS observations collected from the IGS global GPS network. The red dots denote the locations of GPS stations.

al., 2005). The large gradients observed in the VTEC in the southern Brazil and some of the Argentinean stations are due to the geomagnetic storm that has moved the plasma away from the magnetic equator. Lin et al. (2005) have reported similar results during the October-November 2003 superstorm periods. They have reported from the GPS-TEC measurements that the equatorial ionospheric anomaly (EIA) expanded to very high latitudes with large increases of TEC after the storm started. The present results are in conformity with Mendillo (2006).
Figure 10 shows global TEC maps, produced at the Jet Propulsion Laboratory with 15-min resolution using GPS observations collected from the IGS global GPS network, for several periods. The first map (Fig. 10a) between 16:00 $16: 15 \mathrm{UT}$ is before the unusual pre-reversal uplifting in the equatorial region on 29 October. Figure $10 \mathrm{~b}$ to $\mathrm{d}$ and g shows clearly that during the storms of 29 and 30 October prompt penetrating electric fields (PPEFs) in the dayside ionosphere caused extreme $\boldsymbol{E} \times \boldsymbol{B}$ uplift of the equatorial ionospheric anomalies (EIAs) (Verkhoglyadova et al., 2008). In addition, 
(a) 27/10/2003-16:00 UT

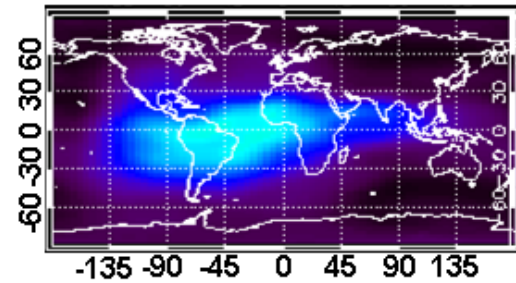

(b) 27/10/2003-20:00 UT

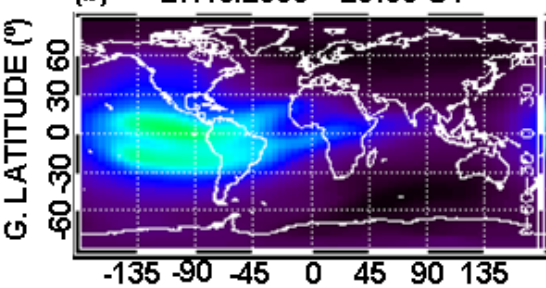

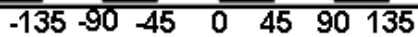

31/10/2003 - 16:00 UT

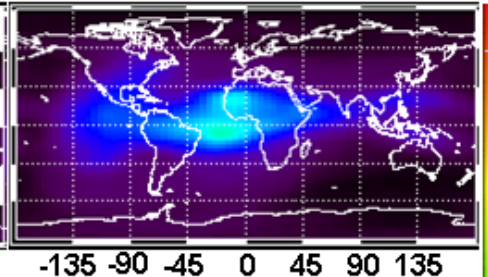

29/10/2003 - 20:00 UT

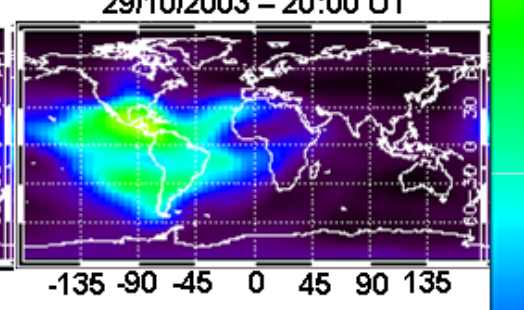

30/10/2003-00:00 UT

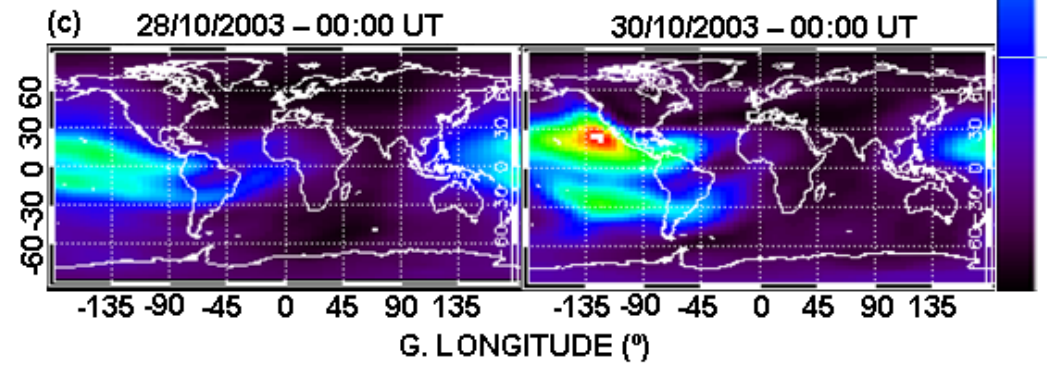

200

150

$100^{\stackrel{己}{\rightleftarrows}}$

50

Fig. 11. Six GPS-derived global TEC maps also produced at the Jet Propulsion Laboratory, with 2-h resolution, for geomagnetically quiet (left hand column) and disturbed (right hand column) conditions.

Fig. 10b to $\mathrm{f}$ shows the global evolution of TEC after the unusual uplifting in the equatorial region in the American sector. Figure $10 \mathrm{~b}$ to $d$ very clearly indicates the intensification and expansion of the EIA to higher latitudes in the South American sector. Again, Fig. 10g shows the EIA after the unususal pre-reversal enhancement on 30 October. Figure 10h shows the daytime TEC variation on 31 October indicating a strong negative storm phase in the South American sector as described earlier.

Figure 11 shows GPS-TEC maps for the same UT observed on a geomagnetically quiet day 27 or 29 October; left hand column) and geomagnetically disturbed or recovery phase day (29-31 October; right hand column). A widespread and drastic TEC changes during the different phases of the geomagnetic disturbances in the South American sector is evident. Figure 11a refers to the daytime comparison during the recovery phase and a strong negative storm phase in the South American sector is observed. Again, Fig. 11b and c shows the development and intensification of the EIA on 29-30 October (UT).

\section{Conclusions}

We have analyzed and presented observations of the ionospheric sounding, all-sky F-region nightglow imaging, and GPS observations obtained at several stations in the South American sector during the super geomagnetic storms on 29 and 30 October 2003. The main results are as follows:

It should be noted that there was uplifting of the F-layer prior to the pre-reversal enhancements. The uplift was enhanced at dusk due to neutral wind effects. The uplifting of the F-layer in the equatorial region during the prereversal enhancement period on 29 and 30 October resulted in the generation of strong equatorial ionospheric irregularities (plasma bubbles) in the Brazilian sector (IMPZ to POAL), seen as phase fluctuations (indicating $\mathrm{km}$ scale ionospheric irregularities). In addition, the Argentinean stations (UNSA, LPGS, VBCA and RWSN), with geomagnetic field lines west of the Brazilian sector (see Table 1) also show strong phase fluctuations close to the pre-reversal enhancement period (after local sunset) indicating the presence of equatorial ionospheric irregularities on the nights of 29-30 and 30-31 October. 
The DMSP satellites plots orbiting at an altitude of about $840 \mathrm{~km}$ are the passages over the South American sector and show large ion density $(\mathrm{Ni})$ fluctuations including unusual depletions close to the magnetic equator. All the DMSP plots show a dip in Ni close to 40 north and 40 south magnetic latitude during this disturbed period. This possibly indicates that the plasmapause moved to lower magnetic latitudes during the intense geomagnetic disturbance.

The southernmost Argentinean station Rio Grande shows very low VTEC (in general) with very low VTEC fluctuations close to the sunset time but accompanied with very large phase fluctuations. This station could be within the SAPS region or even southward of the SAPS region during this intense magnetic storms.

Acknowledgements. We thank the authorities of the "Rede Brasileira de Monitoramento Contínuo de GPS RBMC)", Brazil, for kindly allowing us to use the data obtained by the RBMC. We gratefully acknowledge the Center for Space Sciences at the University of Texas at Dallas and the US Air Force for providing the DMSP thermal plasma data. The ionospheric sounding data reported from Port Stanley were obtained from the site http: //uclar.uml.edu/DIDBase/. We would also like to thank the Brazilian funding agencies CNPq and FAPESP for kindly providing the partial financial support. Thanks are due to Anthea Coster for helpful comments. The work conducted at the Jet Propulsion Laboratory, California Institute of Technology, was under contract with the National Aeronautics and Space Administration.

Topical Editor K. Kauristie thanks H. Chandra and another anonymous referee for their help in evaluating this paper.

\section{References}

Aarons, J., Mendillo, M., and Yantosca, R.: GPS phase fluctuations in the equatorial region during the MISETA 1994 campaign, J. Geophys. Res., 101, 26851-26862, 1996.

Aarons, J., Mendillo, M., and Yantosca, R.: GPS phase fluctuations in the equatorial region during sunspot minimum, Radio Sci., 32, 1535-1550, 1997.

Abalde, J. R., Fagundes, P. R., Bittencourt, J. A., and Sahai, Y.: Observations of equatorial $\mathrm{F}$ region plasma bubbles using simultaneous OI $777.4 \mathrm{~nm}$ and OI $630.0 \mathrm{~nm}$ imaging: New results, J. Geophys. Res., 106, 30331-30336, 2001.

Abdu, M. A.: Major phenomena of the equatorial ionospherethermosphere system under disturbed conditions, J. Atmos. Solar Terr. Phys., 59, 1505-1519, 1997.

Abdu, M. A., Batista, I. S., Takahashi, H., Macdougall, J., Sobral, J. H., Medeiros, A. F., and Trivedi, N. B.: Magnetospheric disturbance induced equatorial plasma bubble development and dynamics, J. Geophys. Res., 108(A12), 1449, doi:10.1029/2002JA009721, 2003.

Abdu, M. A., Maruyama, T., Batista, I. S., Saito, S., and Nakamura, M.: Ionospheric responses to the October 2003 superstorm: Longitude/local time effects over equatorial low and middle latitudes, J. Geophys. Res., 112, A10306,, doi:10.1029/2006JA012228, 2007.

Abdu, M. A., de Paula, E. R., Batista, I. S., Reinisch, B. W., Matsuoka, M. T., Camargo, P. O., Veliz, O., Denardini, C.
M., Sobral, J. H. A., Kherani, E. A., and de Siqueira, P. M.: Abnormal evening vertical plasma drift and effects on ESF and EIA over Brazil-South Atlantic sector during the 30 October 2003 superstorm, J. Geophys. Res., 113, A07313, doi:10.1029/2007JA012844, 2008.

Basu, S., Basu, Su., Groves, K. M., Mackenzie, E., Keskinen, M. J., and Rich, F. J.: Near-simultaneous plasma structuring in the midlatitude and equatorial ionosphere during magnetic superstorms, Geophys. Res. Lett., 32, L12S05, doi:10.1029/2004GL021678, 2005.

Basu, S., Basu, Su., Rich, F. J., Groves, K. M., Mackenzie, E., Coker, C., Sahai, Y., Fagundes, P. R., and Becker-Guedes, F.: Response of the equatorial ionosphere at dusk to penetration electric fields during intense magnetic storms, J. Geophys. Res., 112, A08308, doi:10.1029/2006JA012192, 2007.

Batista, I. S., Abdu, M. A., Souza, J. R., Bertoni, F., Matsuoka, M. T., Camargo, P. O., and Bailey, G. J.: Unusual early morning development of the equatorial anomaly in the Brazilian sector during the Halloween magnetic storm, J. Geophys. Res., 111, A05307, doi:10.1029/2005JA011428, 2006.

Becker-Guedes, F., Sahai, Y., Fagundes, P. R., Lima, W. L. C., Pillat, V. G., Abalde, J. R., and Bittencourt, J. A.: Geomagnetic storm and equatorial spread-F, Ann. Geophys., 22, 3231-3239, 2004 , http://www.ann-geophys.net/22/3231/2004/.

Blanc, M. and Richmond, A. D.: The ionospheric disturbance dynamo, J. Geophys. Res., 85, 1669-1686, 1980.

Bowman, G. G.: Some effects of geomagnetic activity and ionospheric height rises on mid-latitude spread-F occurrence, J. Atmos. Terr. Phys., 46, 55-64, 1984.

Brunini, C., Van Zele, M. A., Meza, A., and Gende, M.: Quiet and perturbed ionospheric representation according to the total electron content from GPS signals, J. Geophys. Res., 108, 1056, doi:10.1029/2002JA009346, 2003.

Buonsanto, M. J.: Ionospheric storms - A review, Space Sci. Rev., 88, 563-601, 1999.

Chakrabarty, D., Sekar, R., Narayanan, R., Patra, A. K., and Devasia, C. V.: Effects of interplanetary electric field on the development of an equatorial spread F event, J. Geophys. Res., 111, A12316,, doi:10.1029/2006JA011884, 2006.

Chandra, H. and Rastogi, R. G.: Equatorial spread-F over a solar cycle, Ann. Geophys., 28, 709-716, 1972.

Chi, P. J., Russel, C. T., Foster, J. C., Moldwin M. B., Engebreston, M. J., and Mann, I. R.: Density enhancement in plasmasphereionosphere plasma during the 2003 Halloween Superstorm: Observations along the 330th magnetic meridian in North America, Geophys. Res. Lett., 32, L03S07, doi:10.1029/2004GL021722, 2005.

Foster, J. C. and Rideout, W.: Midlatitude TEC enhancements during the October 2003 superstorm, Geophys. Res. Lett., 32, L12S04, doi:10.1029/2004GL021719, 2005.

Garner, T. W., Bust, G. S., Gaussiran II, T. L., and Straus, P. R.: Variations in the midlatitude and equatorial ionosphere during the October 2003 magnetic storm, Radio Sci., 41, RS6S08, doi:10.1029/2005RS003399, 2006.

Gopalswamy, N., Barbieri, L., Cliver, E. W., Lu, G., Plukett, S. P., and Skoug, R. M.: Introduction to violent Sun-Earth connection events of October-November 2003, J. Geophys. Res., 110, A09S00, doi:10.1029/2005JA011268, 2005. 
Grant, I. F., MacDougall, J. W., Ruohoniemi, J. M., Bristow, W. A., Sofko, G. J., Koehler, J. A., Danskin, D., and Andre, D.: Comparison of plasma flow velocities determined by the ionosonde Doppler drift technique, SuperDARN radars, and patch motion, Radio Sci., 30, 1537-1549, 1995.

Horvath, I. and Lovell, B. C.: Formation and evolution of the ionospheric plasma density shoulder and its relationship to the superfountain effects investigated during the 6 November 2001 great storm, J. Geophys. Res., 113, A12315, doi:10.1029/2008JA013153, 2008.

Huang, C.-S.: Continuous penetration of the interplanetary electric field to the equatorial ionosphere over eight hours during intense geomagnetic storms, J. Geophys. Res., 113, A11305, doi:10.1029/2008JA013588, 2008.

Huang, C.-S. and Foster, J. C.: Correlation of the subauroral poçarization streams (SAPS) with the $D_{s t}$ index during severe geomagnetic storms, J. Geophys. Res., 112, A11302, doi:10.1029/2007JA012584, 2007.

Huang, C.-S., Foster, J. C., and Sahai, Y.: Significant depletions of the ionospheric plasma density at middle latitudes: A possible signature of equatorial spread $\mathrm{F}$ bubbles near plasmapause, J. Geophys. Res., 112, A05315, doi:10.1029/2007JA012307, 2007.

Kil, H., Paxton, L. J., Su, S.-Y., Zhang, Y., and Yeh, H.: Characteristics of the storm- induced big bubbles (SIBBs), J. Geophys. Res., 111, A10308, doi:10.1029/2006JA011743, 2006.

Lin, C. H., Richmond, A. D., Liu, J. Y., Yeh, H. C., Paxton, L. J., Lu, G., Tsai, H. F., and Su, S.-Y.: Large-scale variations of the low-latitude ionosphere during October-November 2003 superstorm: Observational results, J. Geophys. Res., 110, A09S28, doi:10.1029/2004JA010900, 2005.

Mandea, M. and Macmillan, S.: International Geomagnetic Reference Field: the eighth generation, Earth Planets Space, 52, 11191124, 2000.

Mannucci, A. J., Wilson, B. D., Yuan, D. N., Ho, C. M., Lindqwister, U. J., and Runge, T. F.: A global mapping technique for GPS derived ionospheric total electron content measurements, Radio Sci., 33, 565-583,1998.

Mannucci, A. J., Tsurutani, B. T., Iijima, B. A., Komjathy, A., Saito, A., Gonzalez, W. D., Guarnieri, F. L., Kozyra, J. U., and Skoug, R.: Dayside global ionospheric response to the interplanetary events of October 29-30, 2003 "Halloween Storms", Geophys. Res. Lett., 32, L12S02, doi:10.1029/2004GL021467, 2005.

Mannucci, A. J., Tsurutani, B. T., Abdu, M. A., Gonzalez, W. D., Komjathy, A., Echer, E., Iijima, B. A., Crowley, G., and Anderson, D.: Superposed epoch analysis of the dayside ionospheric response to four intense geomagnetic storms, J. Geophys. Res., 113, A00A02, doi:10.1029/2007JA012732, 2008.

Martinis, C., Mendillo, M. J., and Aarons, J.: Toward a synthesis of equatorial spread $\mathrm{F}$ onset and suppression during geomagnetic storms, J. Geophys. Res., 110, A0306, doi:10.1029/2003JA010362, 2005.

Martinis, C., Baumgardner, J., Smith, S. M., Colerico, M., and Mendillo, M.: Imaging science at El Leoncito, Argentina, Ann. Geophys., 24, 1375-1385, 2006,

http://www.ann-geophys.net/24/1375/2006/.

Mendillo, M.: Storms in the ionosphere: patterns and processes for total electron content, Rev. Geophys., 47, RG4001, doi:10.1029/2005RG000193, 2006.

Meier, R. R., Crowley, G., Strickland, D. J., Christensen, A. B.,
Paxton, L. J., Morrison, D., and Hackert, C. L.: First look at the 20 November superstorm with TIMED/GUVI: Comparisons with a thermospheric global circulation model, J. Geophys. Res., 110, A09S41, doi:10.1029/2004JA010990, 2005.

Nicolls, M. J., Kelley, M. C., Coster, A. J., Gonzalez, S. A., and Makela, J. J.: Imaging the structure of a large-scale TID using ISR and TEC data, Geophys. Res. Lett., 31, L09812, doi:10.1029/2004019797, 2004.

Perevalova, N. P., Afraimovich, E. L., Voeykov, S. V., and Zhivetiev, I. V.: Parameters of large-scale TEC disturbances during the strong magnetic storm on 29 October 2003, J. Geophys. Res., 113, A00A13, doi:10.1029/2008JA013137, 2008.

Rastogi, R. G. and Woodman, R. F.: Spread-F in equatorial ionograms associated with reversal of horizontal F-region electric field, Ann. Geophys., 34, 31-36, 1978.

Rastogi, R. G., Vyas, G. D., and Chandra, H.: Geomagnetic disturbance effects on equatorial spread-F, Proc. Ind. Acad. Sci. Sec. A., 87, 109-113, 1978.

Sahai, Y., Aarons, J., Mendillo, M., Baumgardner, J., Bittencourt, J. A., and Takahashi, H.: OI $630 \mathrm{~nm}$ imaging observations of equatorial plasma depletions at $16^{\circ}$ dip latitude, J. Atmos. Terr. Phys., 56, 1461-1475, 1994.

Sahai, Y., Fagundes, P. R., Becker-Guedes, F., Bolzan, M. J. A., Abalde, J. R., Pillat, V. G., de Jesus, R., Lima, W. L. C., Crowley, G., Shiokawa, K., MacDougall, J. W., Lan, H. T., Igarashi, K., and Bittencourt, J. A.: Effects of the major geomagnetic storms of October 2003 on the equatorial and low-latitude F-region in two longitudinal sectors, J. Geophys. Res., 110, A12S91, doi:10.1029/2004JA010999, 2005.

Sastri, J. H., Niranjan, K., and Subbarao, K. S. V.: Response of the equatorial ionosphere in the Indian (midnight) sector to the severe magnetic storm of July 15, 2000, Geophys. Res. Lett., 29, 1651, doi:10.1029/2002GL015133, 2002.

Schunk, R. W. and Sojka, J. J.: Ionosphere-thermosphere space weather issues, J. Atmos. Terr. Phys., 58, 1527-1574, 1996.

Senior, C. and Blanc, M.: On the control of magnetospheric convection by the spatial distribution of ionospheric conductivities, J. Geophys. Res., 89, 261-284, 1984.

Spiro, R. W., Wolf, R. A., and Fejer, B. G.: Penetration of highlatitude-electric-field effects to low latidudes during SUNDIAL 1984, Ann. Geophys., 6, 39-50, 1988.

Tsurutani, B., Mannucci, A., Iijima, B., Abdu, M. A., Sobral, J. H. A., Gonzalez, W., Guarnieri, F., Tsuda, T., Saito, A., Yumoto, K., Fejer, B., Fuller-Rowell, T. J., Kozyra, J., Foster, J. C., Coster, A., and Vasyliunas, V. M.: Global dayside ionospheric uplift and enhancement associated with interplanetary electric fields, J. Geophys. Res., 109, A08302, doi:10.1029/2003JA010342, 2004.

Tsurutani, B. T., Judge, D. L., Guarnieri, F. L., Gangopadhyay, P., Jones, A. R., Nuttal, J., Zambon, G. A., Didkovsky, L., Mannucci, A. J., Iijima, B., Meier, R. R., Immel, T. J., Woods, T. N., Prasad, S., Floyd, L., Huba, J., Soloman, S. C., Straus, P., and Viereck, R.: The October 28, 2003 extreme EUV solar flare and resultant extreme ionospheric effects: Comparison to other Halloween events and the Bastille Day event, Geophys. Res. Lett., 32, L03S09, doi:10.1029/2004GL021475, 2005.

Tsurutani, B. T., Verkhoglyadova, O. P., Mannucci, A. J., Saito, A., Araki, T., Yumoto, K., Tsuda, T., Abdu, M. A., Sobral, J. H. A., Gonzalez, W. D., McCreadie, H., Lakhina, G. S., and Vasyliunas, V. M.: Prompt penetration electric fields 
(PPEFs) and their ionospheric effects during the great magnetic storm of 30-31 October 2003, J. Geophys. Res., 113, A05311, doi:10.1029/2007JA011879, 2008.

VanZandt, T. E., Peterson, V. L., and Laird, A. R.: Electromagnetic drift of the midlatitude $F_{2}$ layer during a storm, J. Geophys. Res., 76, 278-281, 1971.

Verkhoglyadova, O. P., Tsurutani, B. T., Mannucci, A. J., Saito, A., Araki, T., Anderson, D., Abdu, M., and Sobral, J. H. A.: Simulation of PPEF effects in dayside low-latitude ionosphere for the October 30, 2003, superstorm, in: Midlatitude Ionospheric Dynamics and Disturbances, edited by: Kintner Jr., P. M., Coster, A. J., Fuller-Rowell, T., Mannucci, A. J., Mendillo, M., and Heelis, R., AGU, Washington, D.C., 169-177, 2008.

Wu, C.-C., Wu, S. T., Dryer, M., Fry, C. D., Berdichevsky, D., Smith, Z., Detman, T., Gopalswamy, N., Skoug, R., Zurbuchen, T., and Smith, C.: Flare-generated shock evolution and geomagnetic storms during the "Halloween 2003 epoch": 29 October to 2 November, J. Geophys. Res., 110, A09S17, doi:10.1029/2005JA011011, 2005.
Yizengaw, E., Moldwin, M. B., Dyson, P. L., and Immel, T. J.: Southern Hemisphere ionosphere and plasmasphere response to the interplanetary shock event of 29-31 October 2003, J. Geophys. Res., 110, A09S30, doi:10.1029/2004JA010920, 2005.

Zhang, Y., Paxton, L. J., Kil, H., Meng, C.-I., Mende, S. B., Frey, H. U., and Immel, T. J.: Negative ionospheric storms seen by the IMAGE FUV instrument, J. Geophys. Res., 108(A9), 1343, doi:10.1029/2002JA009797, 2003.

Zhao, B., Wan, W., and Liu, L.: Responses of equatorial anomaly to the October-November 2003 superstorms, Ann. Geophys., 23, 693-706, 2005,

http://www.ann-geophys.net/23/693/2005/. 